\title{
In vitro viral haemorrhagic septicaemia virus replication in excised fins of rainbow trout: correlation with resistance to waterborne challenge and genetic variation
}

\author{
Edwige Quillet ${ }^{1}$, Michel Dorson ${ }^{2, *}$, Gérard Aubard ${ }^{1}$, Corinne Torhy ${ }^{2}$ \\ ${ }^{1}$ Unité de Génétique des Poissons, Institut National de la Recherche Agronomique, 78352 Jouy-en-Josas, France \\ ${ }^{2}$ Unité de Virologie et d'Immunologie Moléculaires, Pathologie Infectieuse et Immunité des Poissons, \\ Institut National de la Recherche Agronomique, 78352 Jouy-en-Josas, France
}

\begin{abstract}
In vitro viral haemorrhagic septicaemia virus replication in excised fin tissue (VREFT) was investigated as a possible criterion to predict the resistance of groups or individuals to viral haemorrhagic septicaemia virus (VHSV) in rainbow trout. Adipose and rayed fins were compared for VREFT response, and a statistically significant correlation was found. Correlation between VREFT and survival after waterborne viral challenge was estimated on a set of 27 groups of trout, and was highly significant $(\mathrm{R}=0.72)$. A further experiment with fish individually tagged and challenged some time after fin clipping for determination of VREFT confirmed that the mean value of resistant (surviving) fish was significantly lower than the mean value of susceptible (dead) ones, but there was a wide variation within each of these groups. In particular, a large proportion of fish expected to be resistant based on VREFT values died all the same. Using clones, we showed that the correlation between VREFT and survival was dramatically high $(\mathrm{R}=0.96)$. Genetic analyses of the data from the different groups available in the experiment consistently indicated a large amount of genetic determination of VREFT, an encouraging result for selection purposes. Though these results were obtained in experimentally controlled conditions not identical to those in the field, they shed new light on the analysis of defence mechanisms against the virus and on the possibility of performing indirect selection for resistance, using VREFT as the secondary character.
\end{abstract}

KEY WORDS: Rainbow trout $\cdot$ Clones $\cdot$ VHSV $\cdot$ Fin $\cdot$ Genetics $\cdot$ Resistance $\cdot$ Disease $\cdot$ Egtved virus

\section{INTRODUCTION}

Viral haemorrhagic septicaemia (VHS) virus (Egtved virus, Jensen 1965) was first recognized as provoking a severe disease in rainbow trout Oncorhynchus mykiss farmed in several European countries. Some serotypes also kill brown trout Salmo trutta (De Kinkelin \& Leberre 1977). The list of known susceptible species (freshwater and seawater) has increased, and viral strains clearly identified as VHSV on a molecular basis

*Corresponding author. E-mail: dorson@biotec.jouy.inra.fr which have no known pathogenic effect on all the salmonid species tested (Winton et al. 1989) but are pathogenic for non salmonid species (Kocan et al. 1997) have been isolated in the wild. Vaccination against VHS is possible by injection of inactivated VHSV or by waterborne administration of attenuated strains of the virus (De Kinkelin 1988), but both manufacturers and trout farmers are reluctant to introduce such a vaccine. DNA immunisation has also been tried successfully (Boudinot et al. 1998, Lorenzen et al. 1999) but use in the field is still a distant goal. Some salmonid species are resistant to the known 
VHSV serotypes and can transmit their resistance to interspecific hybrids (Dorson \& Chevassus 1985, Dorson et al. 1991).

The different facets of successive infection steps and of resistance mechanisms for the 2 important rhabdovirus diseases of salmonids (VHS and infectious haematopoietic necrosis [IHN], the other important salmonid rhabdoviral disease) have been the object of increasing interest during the past few decades. Special attention has been paid to the superficial tissues which are obviously the portal of entry for the virus, a site for the first multiplication and also the seat of the first line of defence. Gills were the first to be considered for VHSV (De Kinkelin et al. 1979, Chilmonczyk 1980, Neukirch 1984, 1985, Konrad et al. 1989) and for IHNV (Yamamoto \& Clermont 1990). One of the first indications of the importance of the skin was the presence of high titres of IHNV in the external mucus (Lapatra et al. 1989). Yamamoto et al. (1990a) observed that IHNV replicated early in the skin of fins following whole fish waterborne infection and Yamamoto et al. (1990b) indicated that an early replication of both rhabdoviruses occurred in the skin following water route infection as well as in vitro infection of excised pieces. A similar observation was made for infectious pancreatic necrosis virus (IPNV, Yamamoto \& Hu 1991), and these authors made the interesting remark that differences in virus multiplication could parallel differences in the susceptibility of fish to the disease. Confirming the important role of superficial tissues, Yamamoto et al. (1992) observed that an avirulent strain of VHSV did not replicate in superficial tissues. We also placed susceptible trout in a VHSV suspension for $1 \mathrm{~h}$, rinsed the fish thoroughly in flowing water for an additional hour and sampled the pelvic fins, which were then incubated $3 \mathrm{~d}$ in culture medium. The virus growth was as high as when the fins were infected in vitro, indicating that for VHSV they were also a natural route of entry and multiplication.

Selection for strains resistant to diseases has become a major goal of salmonid farming, and intraspecific selection for fish resistant to various diseases has been attempted (reviewed by Price 1985, Chevassus \& Dorson 1990, Fjalestad et al. 1993). Encouraging results have been published concerning IHN (Amend \& Nelson 1977, McIntyre \& Amend 1978, Yamamoto et al. 1991) and IPN (Okamoto et al. 1993) caused by a birnavirus. With respect to VHS, the parental effect on susceptibility of progeny and selection of rainbow trout with increased resistance or susceptibility have also been observed (Kaastrup et al. 1991, Slierendrecht et al. 1994, Dorson et al. 1995). Heritability of resistance to VSHV was also estimated (Dorson et al. 1995, Henryon et al. in press). Yet, as for other diseases, selections for experimental as well as for commercial purposes are hampered by the extensive experimentation which is required: individual selection is limited by the fact that survivors may become carriers, and selection on relatives (sibs or progeny) only is limited by the large number of groups that have to be challenged. Thus, an important goal is to determine resistance criteria which would allow us to avoid extensive experimentation. Attempts have been made to correlate susceptibility to VHS with alloforms of 1 complement protein (Slierendrecht et al. 1993, 1996), and progress has been made in identifying correlations between resistance to bacterial and viral fish diseases and major histocompatibility complex (MHC) genes (Van Muiswinkel et al. 1999). Recently, studies to locate molecular markers associated with resistance to IHN were conducted (Palti et al. 1999, Rodriguez et al. 1999), and Trobridge et al. (2000) tried to relate resistance to IHNV with the expression of the antiviral Mx protein gene.

In a preliminary work (Dorson \& Torhy 1993b), we pointed out differences in VHSV multiplication in pieces of superficial organs excised and infected in vitro. These differences seemed to correlate well with the susceptibility of the fish to the disease, and the fins (fins were chosen because excision does not compromise the survival of fish) appeared to be good candidates for predicting the susceptibility of the whole animal in vivo (Dorson et al. 1995). Previous results (Dorson \& Thory 1993a,b) had also suggested that adipose fins could support lower viral replication than rayed ones (pectoral or pelvic).

This paper describes further work to assess the value of viral replication in excised fin tissue (VREFT) as a resistance criterion in trout using assays performed with both groups and individuals. The possible advantage of using VREFT in selection for resistance to VSH in this species is discussed.

\section{MATERIALS AND METHODS}

Brood stock and gamete collection. Rainbow trout breeders originated from an INRA (Institut National de la Recherche Agronomique) 'synthetic strain' (Sy). The strain results from successive introductions between 1976 and 1983 of several domestic populations from USA and France which were pooled and then maintained as a single population by random mating over 4 to 5 generations (around 100 breeders per generation). The strain is kept at the INRA experimental trout farm (Gournay-sur-Aronde, Oise, France) that is free of known viruses and permanently controlled. Two kinds of parents were used in the present paper: normal Sy parents and mitotic gynogens (Gmi) that had been previously produced from Sy females according to the procedure described in Diter et al. (1993) (late heat 
shock $-31^{\circ} \mathrm{C}$ for $5 \mathrm{~min}$ - applied $220 \mathrm{~min}$ after the activation of ova by UV-irradiated sperm). Because they result from the inhibition of the first mitosis of the embryo, Gmi fish are all homozygous and all females. Thus, some had been sex-reversed by hormonal treatment (Cousin-Gerber et al. 1989) to obtain functional XX males. The homozygosity of every Gmi breeder was checked by analysis of allelic variation at 4 microsatellite markers: OmyFGT2TUF (previously FGT2, in Sakamoto et al. 1994), Str73INRA (previously $\mu$ Sat-73 in Estoup et al. 1993, GenBank accession number AB001056), Str2INRA and Omy18INRA (Estoup et al. 1998). Processes for analysis of microsatellite markers are summarised in Estoup et al. $(1993,1998)$.

Gametes were collected and transported on ice to the laboratory to perform fertilisation. Milts were controlled for motility under the microscope by adding 1 drop of buffered saline diluent (Billard 1977).

Fertilisations with both normal and genetically inactivated sperm were performed, the latter to produce some meiotic gynogenetic groups (Gme). Sires from a 'golden' (phenotypic dominant trait) strain were used as sperm donors for gynogenesis. Milt was UVirradiated according to the procedure described by Chourrout (1982), for a minimum duration of $3.5 \mathrm{~min}$, and Gme progenies were obtained by the application of the early heat shock $\left(26.5^{\circ} \mathrm{C}\right.$ for $20 \mathrm{~min}, 20 \mathrm{~min}$ after activation of the ova) defined in Chourrout \& Quillet (1982).

Experimental groups. Data were compiled on a number of groups with different levels of genetic variability. Random samples of the Sy strain represent mixed population with maximum genetic variability (3 samplings). Normal Sy parents were also used to produce sib-families (4 full-sibs and 1 half-sibs) and 2 meiotic gynogenetic families. Seven heterozygous clones (Clo) were produced by mating single Gmi males with non related Gmi females. Finally, 'hemiclones' (HClo) were produced by mating either Gmi females with normal males (8 groups) or normal females with Gmi males (9 groups). Some Gmi parents were used to produce both Clo and HClo progenies.

Rearing conditions. The eggs were incubated in $10 \times$ $10 \mathrm{~cm}$ incubators in a recirculated unit, thermoregulated at $10^{\circ} \mathrm{C}$. At the eyed stage, eggs were disinfected by iodine and transferred to $10 \mathrm{l}$ aquariums supplied with recirculated or with dechlorinated tap water always at $10^{\circ} \mathrm{C}$. Early survivals were highly variable (10 to $90 \%$ at first feeding; low survivals often caused by poor quality of eggs of Gmi females). Yet, this was not considered to be restricting because, in case of selective mortalities, they would have occurred before the assays were performed, so that VREFT and response to challenge were estimated on genetically unchanged groups.
Virus production. VHSV strain 07-71 (serotype 1) isolated from diseased fish from a French trout farm was propagated in epithelioma papulosum cyprini (EPC) cells as described by Dorson et al. (1991). After infection, the cells were incubated at $14^{\circ} \mathrm{C}$ in Stoker's medium (Stoker \& MacPherson 1961), buffered at $\mathrm{pH}$ 7.4 with $0.16 \mathrm{M}$ Tris- $\mathrm{HCl}$, and supplemented with $2 \%$ foetal calf serum and antibiotics (penicillin $100 \mathrm{IU} \mathrm{ml}^{-1}$, streptomycin $0.1 \mathrm{mg} \mathrm{ml}^{-1}$ and kanamycin $0.1 \mathrm{mg} \mathrm{ml}^{-1}$ ). The virus was harvested when the cytopathic effect was completed.

Challenge. The VHSV challenge was performed when the fish were 3 to 5 mo old (weight range for all experiments: 1 to $5 \mathrm{~g}$ ) according to Dorson et al. (1991). Briefly, each progeny was duplicated (from 25 to 100 per group) and 1 group was mock-infected and kept for further determination of VREFT. The water supply of the aquariums was stopped and the infected fish were kept for $2 \mathrm{~h}$ in a $5 \times 10^{4} \mathrm{pfu} \mathrm{ml}^{-1}$ virus suspension with vigorous aeration. The level of mortality was monitored for 1 mo. When an unexpected mortality (more than 5\%) was recorded in a control group, the results were disregarded.

As all progenies could not be challenged at once, a control group (random sample of the Sy strain of the same age) was challenged together with every series, to check the success of the challenge. A few progenies were challenged twice at a 2 mo interval, and showed very similar mortalities in both cases, indicating good repeatability of the process with age. In addition, we were able to check that time to death as well as ultimate resistance of fish of the same age were not correlated with weight within 2 given ranges ( 1 to $6-7 \mathrm{~g}$ and 6 to about $30 \mathrm{~g}$ ). Thus, we assumed that challenge results were independent of size/weight all over the experiments.

In one specific experiment, fish (mean weight $16 \mathrm{~g}$, randomly sampled from Sy strain) were individually tagged by small incisions in the opercula and ablation of different fins (1 pelvic fin being used for VREFT determination) and challenged $24 \mathrm{~d}$ later when wounds had apparently finished healing. The purpose was to correlate the VREFT with the response to challenge (survival or death) of individuals, instead of groups.

Virus growth in excised fins. The pelvic fin, or occasionally anal fin, were used, and the adipose fin was used only for comparison with the pelvic fin (the adipose fin was usually preserved for further tagging of groups if required).

Fins were sampled from 9 to 12 mo old fish previously anaesthetized with phenoxyethanol and were processed immediately following the procedure described by Dorson \& Torhy (1993a): each fin was weighed and immersed $1 \mathrm{~h}$ in $2 \mathrm{ml}$ of Stoker's medium containing $2 \times 10^{5} \mathrm{VHSV}$ pfu ml ${ }^{-1}$ and rinsed 3 times. 
They were incubated for $3 \mathrm{~d}$ at $14^{\circ} \mathrm{C}$ in 6 -well plates. The plates were then frozen at $-80^{\circ} \mathrm{C}$ until virus titration. After thawing, the fins were ground with mortar and pestle together with incubation medium, the debris eliminated by centrifugation and the virus titrated as following. Serial 10-fold dilutions of the sample were inoculated onto EPC (Fijan et al. 1983) monolayers freshly prepared in 6-well plates (Nunc). After a $1 \mathrm{~h}$ adsorption period the cells were covered with $2 \mathrm{ml}$ of Stoker's medium containing $0.4 \%$ agarose. After $3 \mathrm{~d}$ at $14^{\circ} \mathrm{C}$ the cells were fixed by $10 \%$ formalin and stained with $1 \%$ crystal-violet, and the plaques counted. The mean of fin sample weights was 18 (range 5 to 39) mg (juveniles) and 66 (range 21 to 98) $\mathrm{mg}$ (adults). The maximum titre reached in the supernatants was $2 \times 10^{6}$ pfu $\mathrm{ml}^{-1}$. The sensitivity threshold corresponding to $1 \mathrm{pfu}^{\mathrm{dish}}{ }^{-1}$ was $10 \mathrm{pfu} \mathrm{ml}^{-1}$, i.e. approximately $1 \mathrm{pfu}$ $\mathrm{mg}^{-1}$. Therefore 0 means less than $1 \mathrm{pfu} \mathrm{mg}^{-1}$.

Usually 10 to 24 fish, sometimes more (up to 57) were sampled to estimate the mean VREFT of a group. The delay between challenge and fin excision was due to technical constraints, one being the amount of fin tissue available.

Statistical and genetic analyses. The frequency distribution of the VREFT does not fit a normal distribution and is highly skewed to the right (see Fig. 2). To perform linear regression and variance analyses, we accepted the approximation that the logarithmic transformed variable meets the required assumptions. A value of $(-1)$ was conventionally assigned to null values of VREFT. Angular transformation was applied to analyse percentages of mortality after challenge. Oneway or 2-way ANOVA (unequal sample size) were performed assuming the effect of the fin to be fixed, and the effect of crosses to be random.

In order to estimate the relative magnitude of genetic component in the variability of VREFT, we first used the degree of genetic determination $V_{\mathrm{G}} / V_{\mathrm{P}}$. The calculation of the ratio $V_{\mathrm{G}} / V_{\mathrm{P}}$ requires that the total phenotypic variance of the trait $\left(V_{\mathrm{P}}\right)$ is partitioned into its genotypic $\left(V_{\mathrm{G}}\right)$ and environmental $\left(V_{\mathrm{E}}\right)$ components. The $V_{\mathrm{P}}$ of a random sample of the strain (genetically mixed population) estimates the genotypic and environmental variances together. In accordance with Falconer (1989, p. 127), we used the within-clone phenotypic variance to estimate the $V_{\mathrm{E}}$ alone, which provided a first estimate of $V_{\mathrm{G}}$ by subtraction. On the other hand, the variance between clones arises mainly from the genetic differences. In our case, clones have random heterozygous genotypes, just as random individual fish of the strain, so that the between-clone variance component also provides an estimate of $V_{\mathrm{G}}$ in the population. Another way to express the extent to which a trait is genetically determined is to estimate its heritability. This can be done from an analysis of co- variance between relatives. The genetic model and computation formulas to analyse full-sibs data are described in Becker (1985, single pair mating). We adapted computations of genetic variance and covariance to the specific case of data from hemiclones (detailed in the Appendix). Briefly, heritability $\left(h^{2}\right)$ was estimated as follows:

$h^{2}=2 \sigma_{\mathrm{B}}^{2} /\left(\sigma^{2}{ }_{\mathrm{B}}+\sigma^{2}{ }_{\mathrm{W}}\right)$ in the case of full-sib families, and $h^{2}=4 / 3 \sigma_{\mathrm{B}}^{2} /\left(\sigma_{\mathrm{B}}^{2}+\sigma^{2}{ }_{\mathrm{W}}\right)$ in the case of hemiclones,

where $\sigma^{2}{ }_{\mathrm{B}}$ and $\sigma^{2}{ }_{\mathrm{W}}$ are the between-group and withingroup components of variance in both cases.

\section{RESULTS}

\section{Comparison of VREFT obtained with adipose and pelvic fins}

Both adipose and pelvic fins were sampled at the same time from a group of 54 individual fish (about 10 mo old) and VREFT was determined in both cases. Mean values of VREFT obtained from the adipose or pelvic fin of the same fish were $1003 \pm 452$ and $1381 \pm$ $471 \mathrm{pfu} \mathrm{mg}^{-1}$ respectively $(1.49 \pm 0.20$ and $1.67 \pm 0.19$ respectively for means of log values). ANOVA showed that these values were not significantly different $\left(F_{(1,106)}=0.44 ; \mathrm{p}=0.51\right.$ on log values $)$, and regression analysis showed that they were significantly correlated $\left(\mathrm{R}=0.71 ; F_{(1,52)}=52.1, \mathrm{p}<0.001\right)$ (Fig. 1).

\section{Distribution of VREFT in the control population}

A random sample of 101 fish from the Sy control population was checked for VREFT values measured on

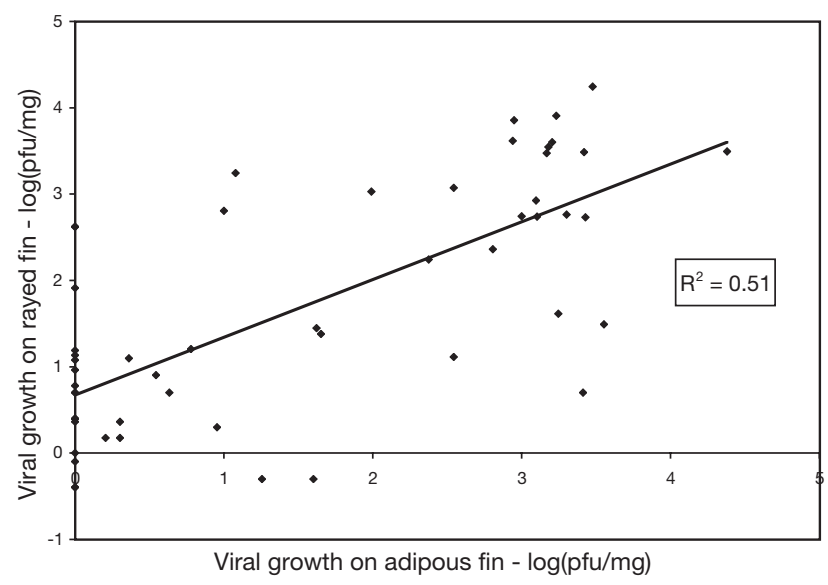

Fig. 1. Regression between the VREFT values of adipose and rayed fins sampled at the same date on different fish (54 pairs of data, analysis performed on the logarithm of VREFT values) 


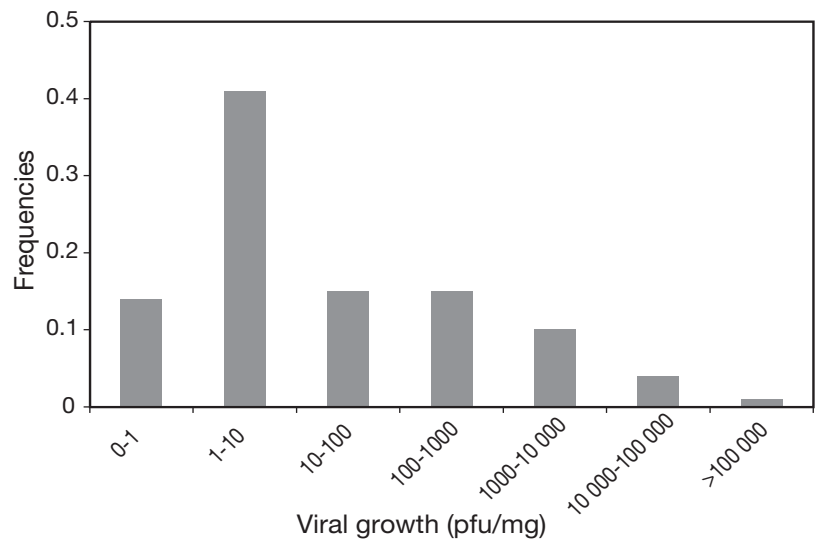

Fig. 2. Frequency distribution of VREFT in a random sample of the Sy strain (101 individuals). (Logarithmic scale, each class includes values equal to the upper mark of the interval)
VREFT are given in Table 4. They are consistent whatever the method, and confirm that a large proportion of the variation of VREFT is genetically determined.

\section{Correlation between VREFT and susceptibility of groups of fish}

Clones will be considered in the next section. In other groups, mortalities after viral challenge ranged from 0 to $100 \%$ (Table 1), while the mortality in Sy controls ranged from 66 to $95 \%$. The regression curve between VREFT and mortalities is shown in Fig. 3. It is highly significant $\left(\mathrm{R}=0.72 ; F_{(1,25)}=26.9\right.$, $\mathrm{p}<0.001)$. the pelvic fin. The frequency distribution of the trait (Fig. 2) is very large ( 0 to more than 100000 pfu $\mathrm{mg}^{-1}$ ) and displays a skewed shape, with a high number of 'medium-low' values. In the Sy strain, the mortality usually recorded after challenge was around 70 to $80 \%$.

\section{Environmental and genetic sources of variation of VREFT}

Table 1 summarizes mean VREFT values and mortalities recorded after challenge for the 34 groups we analysed. Mean values of VREFT ranged from 1.6 to more than $4000 \mathrm{pfu} \mathrm{mg}^{-1}$. There was a significant effect of the group for the whole set of data $\left(F_{(23,341)}=15.6, \mathrm{p}<0.001\right.$, ANOVA performed for all groups excepting clones and controls). There was also a significant effect of the family within each different type of groups (see Table 2), a result which is in favour of a significant genetic control of the trait. Estimates of the within- and between-group components of variance in the different types of groups (sib families, hemiclones and clones) are detailed in Table 3. The reduction of the withingroup component recorded from sibs to clones is consistent with the underlying reduction of genotypic variance in the groups, and also supports the hypothesis of a substantial genetic control of the trait. The estimated values of the genetic determination and heritability of
Table 1. Mean values of VREFT and mortalities after challenge in the different groups

\begin{tabular}{|c|c|c|c|c|c|}
\hline \multirow{2}{*}{$\begin{array}{l}\text { Genetic struc- } \\
\text { ture of groups }\end{array}$} & \multirow{2}{*}{ Crosses } & \multirow{2}{*}{$\begin{array}{c}\text { Mortality } \\
(\%)\end{array}$} & \multicolumn{3}{|c|}{ VREFT (pfu $\mathrm{mg}^{-1}$ ) } \\
\hline & & & No. of fins & Mean & Range \\
\hline \multirow{5}{*}{$\begin{array}{l}\text { Sy strain } \\
\text { (random) }\end{array}$} & Sy 1 & 92 & 57 & 4443 & $1-150000$ \\
\hline & Sy 2 & 71 & 10 & 3169 & $0.4-20000$ \\
\hline & Sy 3 & 66 & 11 & 1295 & $2.9-14000$ \\
\hline & Sy 4 & $76 / 78^{\mathrm{b}}$ & - & - & - \\
\hline & Sy 5 & $95 / 95^{\mathrm{b}}$ & - & - & - \\
\hline \multirow[t]{5}{*}{ Sib families ${ }^{a}$} & HS 1 & $100 / 100^{\mathrm{b}}$ & 24 & 2900 & $2-15570$ \\
\hline & FS 2 & 52 & 21 & 4.8 & 0-39 \\
\hline & FS 3 & 16 & 12 & 14.3 & $1.3-71$ \\
\hline & FS 4 & 32 & 12 & 179 & $2-1786$ \\
\hline & FS 5 & 5 & 10 & 2.5 & $0-8.3$ \\
\hline \multirow[t]{2}{*}{ Gynogenetics } & Gme1 & 44 & 12 & 1895 & $2-18750$ \\
\hline & Gme2 & 11 & 21 & 3.9 & $0-44$ \\
\hline \multirow[t]{17}{*}{ Hemiclones } & HClo 1 & $100 / 100^{\mathrm{b}}$ & 30 & 769 & $9-9,090$ \\
\hline & HClo 2 & 92 & 12 & 2985 & $0.5-27272$ \\
\hline & HClo 3 & 88 & 12 & 295 & $0-2500$ \\
\hline & HClo 4 & 76 & 18 & 938 & $0.7-14286$ \\
\hline & HClo 5 & 76 & 12 & 4092 & $1.6-48000$ \\
\hline & HClo 6 & 60 & 24 & 239 & $0-3,034$ \\
\hline & HClo 7 & $64 / 52^{\mathrm{b}}$ & 24 & 2.2 & $0-3.8$ \\
\hline & HClo 8 & 52 & 12 & 12.1 & $0.4-56$ \\
\hline & HClo 9 & 48 & 12 & 200 & $3.7-1133$ \\
\hline & HClo 10 & 36 & 12 & 37.2 & $0.5-283$ \\
\hline & HClo 11 & 20 & 12 & 82 & $0.3-367$ \\
\hline & HClo 12 & 8 & 12 & 1.8 & $0.2-8$ \\
\hline & HClo 13 & 4 & 12 & 6.1 & $2.5-9.4$ \\
\hline & HClo 14 & 4 & 18 & 419 & $0.7-3750$ \\
\hline & HClo 15 & 0 & 30 & 2.7 & $0-12$ \\
\hline & HClo 16 & 0 & 12 & 1.6 & $0-12$ \\
\hline & HClo 17 & 0 & 12 & 2.3 & $0-5.3$ \\
\hline \multirow{7}{*}{ Clones } & Clo 1 & 70 & 24 & 1312 & $1.5-5000$ \\
\hline & Clo 2 & 52 & 12 & 930 & $1.7-4333$ \\
\hline & Clo 3 & 48 & 12 & 111 & $2.5-382$ \\
\hline & Clo 4 & 28 & 24 & 43.2 & $0-420$ \\
\hline & Clo 5 & 4 & 18 & 2.2 & $0-9$ \\
\hline & Clo 6 & 0 & 18 & 13.2 & $0-200$ \\
\hline & Clo 7 & - & 12 & 863 & $18-2500$ \\
\hline \multicolumn{6}{|c|}{${ }^{\mathrm{a}} \mathrm{HS}=$ half sibs, $\mathrm{FS}=$ full sibs } \\
\hline
\end{tabular}


Table 2. One-way analyses of variance of VREFT in the different groups. Analyses were performed on logarithmic transformed values of VREFT

\begin{tabular}{|llrrc|}
\hline $\begin{array}{l}\text { Genetic } \\
\text { relationship }\end{array}$ & $\begin{array}{l}\text { Source of } \\
\text { variation }\end{array}$ & df & MS & $F$ \\
\hline Full sibs & Among groups & 3 & 4.39 & $9.1^{* * *}$ \\
& Within groups & 42 & 0.48 & \\
Hemiclones & Among groups & 16 & 12.06 & $15.28^{* * *}$ \\
& Within groups & 259 & 0.79 & \\
Clones & Among groups & 6 & 29.52 & $34.9^{* * *}$ \\
& Within groups & 113 & 0.85 & \\
${ }^{* * *}$ All critical probabilities are less than $1 \times 10^{-4}$ & \\
\hline
\end{tabular}

\section{Correlation between VREFT and susceptibility of individual and cloned fish}

The first experiment to assess the potential of VREFT as a criterion to anticipate the susceptibility of individual fish was performed with individual Sy control fish that were tested both in vivo and in vitro (see 'Materials and methods'). For every fish, response to challenge (survival or death) was recorded, and related to the corresponding VREFT. Fig. 4 shows the frequency distribution of VREFT in the 2 groups of fish. The mean VREFTs in susceptible and resistant fish were $2.12 \pm$ 0.25 and $1.05 \pm 0.18 \log \left(\mathrm{pfu} \mathrm{mg}^{-1}\right)$ respectively and were significantly different $\left(F_{(1,56)}=10.29, \mathrm{p}=0.002\right)$. Yet, many fish did not behave as expected from their VREFT. Some survivors supported fairly good viral replication in fins and, more outstandingly, a large proportion (more than one-third) of the fish with a very low VREFT ( $<10 \mathrm{pfu} \mathrm{mg}^{-1}$ ) died all the same.

Clones were used in a second experiment. In this case, a random sample of fish from each clone (i.e. of each genotype) was challenged with VHSV, while the rest of the fish were allowed to grow further until fin clipping and an estimation of the mean VREFT value of the clone was made. Few clones were available to establish the regression between VREFT and survival, but fortunately, their susceptibility was almost evenly

Table 3. Variance components of VREFT (\%) according to the within group genetic relationship

\begin{tabular}{|lrcr|}
\hline & $\begin{array}{c}\text { Full-sib } \\
\text { families }\end{array}$ & $\begin{array}{c}\text { Hemi- } \\
\text { clones }\end{array}$ & Clones \\
\hline Between-group component & 41 & 48 & 66 \\
Within-group component & 59 & 52 & 34 \\
Total phenotypic variance & 100 & 100 & 100 \\
Number of groups & 4 & 17 & 7 \\
\hline
\end{tabular}

Table 4. The different estimations of the genetic determination of VREFT. $V_{\mathrm{G}}$ : genotypic variance; $V_{\mathrm{P}}$ : phenotypic variance; $h^{2}$ : heritability

\begin{tabular}{|lcc|}
\hline Set of data & Method of estimation & Value \\
\hline Clones & $V_{\mathrm{G}} / V_{\mathrm{P}}$ & 0.66 \\
Mixed population ${ }^{\mathrm{a}}$ & $V_{\mathrm{G}} / V_{\mathrm{P}}$ & 0.60 \\
Hemiclones & $h^{2}$ & $0.63 \pm 0.13$ \\
Full-sib families & $h^{2}$ & $0.83 \pm 0.46$ \\
${ }^{\mathrm{a}}$ Random sample of 101 fish of the strain & \\
\hline
\end{tabular}

distributed ( 0 to $70 \%$ mortality after challenge). Fig. 3 shows that the resulting correlation is dramatically high $\left(\mathrm{R}=0.96 ; F_{(1,4)}=50.5, \mathrm{p}=0.002\right)$.

\section{DISCUSSION}

In this work we focused on the value of VREFT as a criterion of resistance or susceptibility of fish and tried to make a first estimation of its merit as a secondary character to manage indirect selection schemes for resistance.

The pelvic fin was regularly used for the in vitro virus growth experiments, but it was useful to know if the adipose fin could also be used. The correlation between the 2 types of fins was good. A preliminary check has shown that the anal fin could also be used if necessary (especially when both adipose and pelvic fins had already been used for identification). Another reason to use the anal fin was the state of the fin. It has often been observed that when trout are crowded together the pectoral fins are generally reduced to stumps, apparently due to biting. This situation is sometimes extended to pelvic and caudal fins. Anal

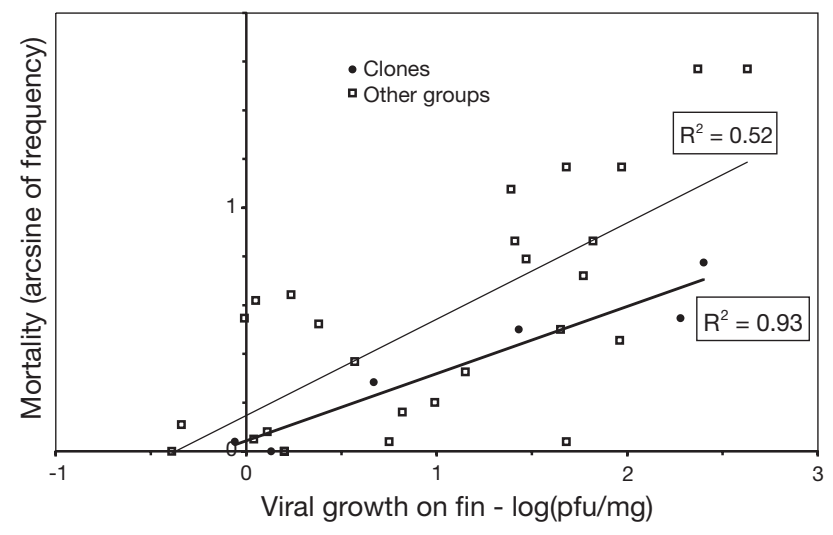

Fig. 3. Regressions of survival after VHSV challenge (arcsinetransformed proportions) on the VREFT values (log-transformed) in 2 sets of data: all types of groups and clones 


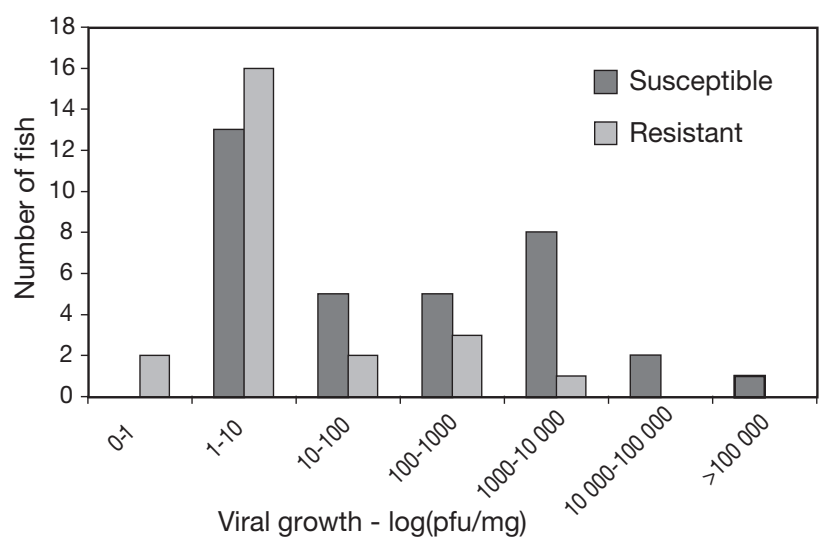

Fig. 4. Frequency distribution of VREFT values of individual fish according to their response to the VHSV challenge (death or survival). (Logarithmic scale, each class includes values equal to the upper mark of the interval)

and adipose fins usually remain intact. The eroded fins are often the target for pathogens. In our conditions this could be the case only for opportunistic bacteria from the environment. It is easy to understand that in some cases an injury to the fin will reduce the ability of the virus to replicate, probably due to impairment of viral protein synthesis by damaged cells, and these fish can then be considered as 'false resistant' individuals. This was very likely the case for some of the groups we used here (FS2, HClo 6 and HClo 7). Though no precise experiment has been performed to confirm this, a check of trout farm fish data strengthens this interpretation.

On the whole, we observed extreme responses to the virus challenge ranging from totally resistant to extremely susceptible groups. In this latter case the kinetics of mortality, not detailed here, were extremely rapid compared to the Sy strain, and all the fish died within 2 wk. Fish in these extreme groups appeared very homogeneous. The case of some clones with intermediate mortality was particularly interesting: mortality in those groups occurred over a range of time as large as in the Sy control population, in spite of the genetic identity of the clonal fish. We can assume that these clones possessed genetically determined 'medium' resistance mechanisms and that the outcome of the fight against the virus is uncertain, and ultimately depends on casual individual epigenetic or social factors.

The distribution of VREFT in the control population was extremely wide, with a high number of 'mediumlow' individuals. Our Sy strain is a mixture of several populations and is expected to display a large genetic variability, which certainly contributes to this wide distribution of the observed variability. As for mortalities, the different groups tested displayed extremely vari- able mean values of VREFT. The totally resistant groups provided low and relatively homogenous values, while the totally susceptible groups exhibited high but more heterogeneous values.

The phenotypic correlation between VREFT and resistance to VHSV was studied for both groups and individuals. A good correlation for groups would be useful for sorting strains or families for resistance, while correlation for individuals could help us comprehend the pathways of resistance and select fish that could be used as breeders (survival or sanitary status not impaired by the selection process).

Under our experimental conditions, we demonstrated that VREFT was a quite good predictor of the mean resistance of groups or families, as it contributed up to about $50 \%$ of the variance of the mortality of the groups. We have to underline that we worked under 'optimised' conditions. The fish were reared in a specific pathogen-free environment and were tested in an age/weight range within which there was no important ontogenic variation in susceptibility. Moreover, most of the tested groups were hemiclones, which display greater genetic homogeneity than conventional families and are thus expected to display more homogenous responses. For all these reasons, our results may not be directly extended to the field. After regression, the residuals of a few groups were quite large: the 'false resistant' ones discussed above, and 'false susceptible' one (HClo 14), which exhibited a very low but not null mortality, despite a relatively high value of VREFT. In fact, the distribution of the individual values of VREFT in this group shows that most of the fish had a very low VREFT value, and only a few (3 fish out of 18) had dramatically high values (very likely the ones that would die during challenge).

A complementary aim of this paper was to determine whether VREFT was related to resistance at the individual level. A first attempt with synthetic fish resulted in an incomplete correlation: as expected, the mean VREFTs of resistant and susceptible fish were significantly different, but a high number of fish died despite a low VREFT. One possible explanation for this is that the wounds caused by tagging and excision had not completely healed, allowing a rapid and uncontrolled penetration of the virus. This hypothesis is strengthened by the results of infection by intraperitoneal injection of a relatively high dose of virus (Dorson \& Thory 1993a, and additional unpublished experiments) which bypasses the superficial defence mechanisms. The second possible explanation is that a particular fish that dies or survives the challenge does not rely on its genetic level of resistance only, which is confirmed by the wide range of time to death in clones of intermediate resistance (data not shown). Thus, the discrete response (death/survival) obtained for each single fish 
in this experiment does not faithfully reflect actual resistance, at least for 'intermediate' fish.

More conclusive results were obtained with clones, which were particularly well suited to overcoming previous limitations. From a genetic point of view, clonal fish are replications of any single fish (i.e. genotype). Thus, they allow the determination of both survival and VREFT of a given fish without any interference, as different fish of the clone may be used for each trait. Another advantage of clones is increased precision in the estimation of trait values, because repeated measures can be performed very simply. With regard to resistance status, an important point is that challenge with the virus can be repeated a number of times for the same fish (genotype), which provides a continuous response for susceptibility, instead of the usual discrete one, and is much more informative about the actual level of resistance. Using clones, we showed that the underlying VREFT contributed most to the variance of survival (more than $90 \%$ ). There has been no previous evidence in the literature of such a strong relationship between resistance and any of the criteria tested (Slierendrecht et al. 1996, Palti et al. 1999, Rodriguez et al. 1999).

This result provides evidence of the important role of superficial tissues in resistance. There is certainly also a correlation between virus replication in superficial tissues and some internal ones (spleen), but not others (kidney, muscle, thymus), as suggested by preliminary observations (Dorson \& Thory 1993b, 1994), and it is still difficult to separate the role of early superficial defence mechanisms and internal ones. This work was not aimed at elucidating these mechanisms, but several observations can, nonetheless, be made. It is obvious from our results that poor virus multiplication occurs in superficial tissues of resistant trout but that the virus reaches the internal target organs since it is regularly observed that some of the resistant fish become carriers. Compared to injections, which very likely overwhelm the internal defences, the number of infectious particles transmitted to internal organs via superficial tissues must be lower and/or accompanied by a protective mechanism such as interferon or correlated antiviral proteins. Nevertheless, interferon has not been detected in infected superficial tissues, and has been considered as paralleling virus (Dorson \& Torhy 1994). An interesting path of research to pursue is certainly the Mx protein, but Trobridge et al. (2000) have observed the same pattern of Mx expression in IHNV resistant and susceptible trout. The role of the cell receptors (a receptor for VHSV has been identified by Béarzotti et al. 1999) could also be important, certainly under the control of MHC.

Cell cultures from in vivo resistant and susceptible trout displaying the corresponding in vitro properties with respect to virus multiplication would be a useful tool for the study of cellular resistance mechanisms. Estepa et al. (1993) have obtained cell culture from fins which replicated VHSV, but they gave no information about the status of the donors. Some encouraging results have been published by Chen et al. (1990), who noticed differences in IHNV titres in cell lines from 3 species of salmonids which more or less paralleled the susceptibility of the fish, though this may not be a general feature (for example EPC cells are susceptible to VHSV while the carp is resistant). A promising approach is the use of cell cultures developed from clones of fish which have already been obtained (Ristow et al. 1998, M.D. unpubl.) and are being used in immunology and pathogenicity research.

The high correlation between VREFT and individual resistance is also interesting for selection purposes. Indeed, survivors of the VSHV challenge can become carriers, and can no longer be used as breeders. Thus, selection for resistance must be performed on relatives (sibs or progenies), which requires extensive experimentation. The identification of a reliable resistance criterion would represent great progress. Taking strictly genetic considerations into accounts, 2 parameters are decisive for predicting if indirect selection on a secondary character can be more efficient than direct selection on the desired trait itself (Falconer 1989): the heritability of the secondary character on which selection would be applied (which should be higher than the heritability of the desired trait), and its genetic correlation with the desired character (which should be high too). We have no data about the latter, but the extremely high phenotypic correlation (close to 1) between survival and VREFT gives reason to hope that the genetic correlation is high as well. Concerning the former, very few estimates of heritability of the resistance itself are available. Dorson et al. (1995) have found a fairly high heritability $(0.63 \pm 0.26)$. Henryon et al. (in press) published a much lower value (0.13), but these results are difficult to compare because resistance was not measured the same way (Dorson et al. worked with the final survival after waterborne challenge, while Henryon et al. measured resistance as the time to death). Our results consistently indicate a large amount of genetic determination of VREFT. Though our estimates are all overestimates of heritability in the narrow sense (they all include a fraction of either environmental or dominance variance components), they suggest that heritability of VREFT, if not higher than heritability of resistance itself, is probably quite high. Besides, practical matters may make indirect selection preferable, even if genetic parameters are not totally favourable (Falconer 1989). This is clearly the case for disease resistance (the desired character is difficult and costly to measure). Thus, VREFT may actually be a 
valuable secondary character. Its main practical advantage is that the required sampling is extremely simple. The main limitations are, firstly, the complete processing of the sample, which must begin within $24 \mathrm{~h}$ and requires a specialised virological equipment, and, secondly, the risk of detecting 'false resistant' fish. This point has to be further investigated, but a solution may be found in repeated measures of VREFT in space (different fins) or in time on the same individuals.

In conclusion, VREFT appeared as a very good predictor of the resistance or susceptibility of a fish in the 'ideal' situation: repeated measures on individuals (clones), free of pathogens, reared in non-stressing conditions. Simultaneously, encouraging estimations of genetic parameters make VREFT a good candidate for indirect selection for resistance. Though the experimental conditions described here do not match those in the field, it seems from our first results that it is worth studying VREFT, and work is in progress for assessing its value as a predictor of the breeding value of adult fish.

Acknowledgements. The authors are indebted to the technical staffs at both the 'Installations Piscicoles Expérimentales' and the experimental trout farm in Gournay-sur-Aronde and to M. G. Hollebecq, R. Guyomard and P. De Kinkelin for their help during different stages of the work. This work was supported by the INRA 'Action Incitative Programmée' 'Génétique et Pathologie'.

Appendix 1. Estimation of heritability from 'hemiclone sibs' design

Two different parental populations have to be considered:

(1) The control population (Sy strain), which is assumed to meet all the assumptions of a random breeding population (HardyWeinberg equilibrium, random mating).

(2) The Gmi population, which contains only homozygous individuals. Gmi fish were produced by inhibition of first mitosis of embryos from random females of the control population. No selection associated with homozygosity and no sex effect on the trait under consideration are assumed.

The progeny population contains 'sib families', each of them being produced by random mating between 1 control and 1 Gmi parent. Such progenies have been called 'hemiclones' (HClo).

In the following, all genetic terms and associated symbols will be those used by Falconer (1989).

\section{Allelic and genotypic frequencies}

Let us consider 1 locus of the control population with 2 alleles, $\mathrm{A}_{1}$ and $\mathrm{A}_{2}$, and let their frequencies be $p$ and $q$ respectively. As no selection has been assumed in Gmi population, the genotypes and genotypic frequencies will be:

\begin{tabular}{lcc} 
Genotypes & \multicolumn{2}{c}{ Frequency } \\
& In control population & In Gmi population \\
\hline $\mathrm{A}_{1} \mathrm{~A}_{1}$ & $p^{2}$ & $p$ \\
$\mathrm{~A}_{1} \mathrm{~A}_{2}$ & $2 p q$ & 0 \\
$\mathrm{~A}_{2} \mathrm{~A}_{2}$ & $q^{2}$ & $q$
\end{tabular}

The genotypes and genotypic frequencies in the HClo progeny population will result from random mating between control and Gmi parents:

\begin{tabular}{|c|c|c|c|c|c|c|}
\hline \multicolumn{2}{|c|}{ Control parent } & \multicolumn{2}{|c|}{ Gmi parent } & \multirow{2}{*}{$\begin{array}{l}\text { Frequency } \\
\text { of matings }\end{array}$} & \multirow{2}{*}{$\begin{array}{l}\text { Genotypes } \\
\text { of progenies }\end{array}$} & \multirow{2}{*}{$\begin{array}{c}\text { Mean genotypic value } \\
\text { of progenies }\end{array}$} \\
\hline Genotype & Frequency & Genotype & Frequency & & & \\
\hline $\mathrm{A}_{1} \mathrm{~A}_{1}$ & $p^{2}$ & $\mathrm{~A}_{1} \mathrm{~A}_{1}$ & $p$ & $p^{3}$ & $\mathrm{~A}_{1} \mathrm{~A}_{1}$ & a \\
\hline $\mathrm{A}_{1} \mathrm{~A}_{2}$ & $2 p q$ & $\mathrm{~A}_{1} \mathrm{~A}_{1}$ & $p$ & $2 p^{2} q$ & $1 / 2 \mathrm{~A}_{1} \mathrm{~A}_{2}+1 / 2 \mathrm{~A}_{1} \mathrm{~A}_{1}$ & $1 / 2(d+a)$ \\
\hline $\mathrm{A}_{2} \mathrm{~A}_{2}$ & $q^{2}$ & $\mathrm{~A}_{1} \mathrm{~A}_{1}$ & $p$ & $p q^{2}$ & $\mathrm{~A}_{1} \mathrm{~A}_{2}$ & $d$ \\
\hline $\mathrm{A}_{1} \mathrm{~A}_{1}$ & $p^{2}$ & $\mathrm{~A}_{2} \mathrm{~A}_{2}$ & $q$ & $p^{2} q$ & $\mathrm{~A}_{1} \mathrm{~A}_{2}$ & $d$ \\
\hline $\mathrm{A}_{1} \mathrm{~A}_{2}$ & $2 p q$ & $\mathrm{~A}_{2} \mathrm{~A}_{2}$ & $q$ & $2 p q^{2}$ & $1 / 2 \mathrm{~A}_{1} \mathrm{~A}_{2}+1 / 2 \mathrm{~A}_{2} \mathrm{~A}_{2}$ & $1 / 2(d-a)$ \\
\hline $\mathrm{A}_{2} \mathrm{~A}_{2}$ & $q^{2}$ & $\mathrm{~A}_{2} \mathrm{~A}_{2}$ & $q$ & $q^{3}$ & $\mathrm{~A}_{2} \mathrm{~A}_{2}$ & $-a$ \\
\hline
\end{tabular}

Then, the 3 genotypes $\mathrm{A}_{1} \mathrm{~A}_{1}, \mathrm{~A}_{1} \mathrm{~A}_{2}$ and $\mathrm{A}_{2} \mathrm{~A}_{2}$ are present in the HClo population at the same frequencies that in the control population $\left(p^{2}, 2 p q\right.$ and $q^{2}$ respectively), and the population mean genotypic value (using arbitrary values $a_{1} d$ and $(-\mathrm{a})$ for $\mathrm{A}_{1} \mathrm{~A}_{1}$, $\mathrm{A}_{1} \mathrm{~A}_{2}$ and $\mathrm{A}_{2} \mathrm{~A}_{2}$ genotypes respectively, see Falconer 1989) is: ${ }_{\text {HCLo }} M=a(p-q)+2 d p q$ (which is equal to the control population mean).

\section{Genotypic variances}

If epistatic interactions are ignored, the genotypic variance in the control population is:

$$
V_{\mathrm{G}}=V_{\mathrm{A}}+V_{\mathrm{D}}
$$

with $V_{\mathrm{A}}$ and $V_{\mathrm{D}}$ the additive and dominance components of variance respectively. 
(Appendix 1 continued)

In the Gmi population, all fish are fully homozygous, and the situation is that of a population with an inbreeding coefficient $F$ $=1$. Thus, the genotypic variance becomes:

$$
\mathrm{Gmi}_{\mathrm{G}}={ }_{\mathrm{Gmi}} V_{\mathrm{A}}+{ }_{\mathrm{Gmi}} V_{\mathrm{D}}=2 V_{\mathrm{A}}
$$

because $_{\mathrm{Gmi}} V_{\mathrm{D}}=0$ (no heterozygous individuals in the population) and $\mathrm{Gmi}_{\mathrm{A}} V_{\mathrm{A}}=(1+F) V_{\mathrm{A}}$.

In the HClo population, genotypic frequencies are the same than in control population. Thus, the total genotypic variance will be the same too:

$$
\text { HClo } V_{\mathrm{G}}=V_{\mathrm{A}}+V_{\mathrm{D}}
$$

Genetic covariance in hemiclones. Consider first the covariance due to the additive variance alone. The expected mean genotypic value of a group of hemiclone 'sibs' is then equal to the mean breeding values of the 2 parents. Let $\mathrm{A}$ and $\mathrm{Gmi}_{\mathrm{i}} \mathrm{A}$ be the breeding values of the control and the Gmi parent respectively. Then, the covariance is the variance of $1 / 2(\mathrm{~A}+\mathrm{Gmi} A)$, which is from Eq. (2):

$$
1 / 4\left(V_{\mathrm{A}}+{ }_{\mathrm{Gmi}} V_{\mathrm{A}}\right)=3 / 4 V_{\mathrm{A}}
$$

Now consider the contribution of dominance. In hemiclones, one of the parents brings 1 allele only instead of 2 whatever the locus, and the probability that any pair of hemiclone sibs have the same genotype through identity by descent will be $1 / 2$. Thus, the corresponding covariance due to dominance variation in hemiclones will be: $1 / 2 V_{\mathrm{D}}$ (Falconer 1989, p. 156).

The total covariance of hemiclone sibs is then:

$$
\mathrm{HClo} \mathrm{Cov}=3 / 4 V_{\mathrm{A}}+1 / 2 V_{\mathrm{D}}
$$

This value of hemiclone sibs covariance was also checked using the detailed method of calculation (from the genotypic values of the different types of progenies listed in the last column of previous table, computations not shown).

Because the total genotypic variance in hemiclone population is the same than in the control population (Eq. 3), the withingroup component of genotypic variance of hemiclone sibs is easily obtained by substraction and is equal to: ${ }^{1 / 4} V_{\mathrm{A}}+{ }^{1 / 2} V_{\mathrm{D}}$.

\section{Estimation of heritability}

Heritability was then estimated from the usual connections between the statistical components of the analysis of variance of phenotypic data and the genetic components previously calculated. The computations were adapted from those described in the case of single pair matings in Becker (1985, p. 52).

Thus $h^{2}=\frac{4 / 3 \sigma_{\mathrm{B}}^{2}}{\sigma_{\mathrm{B}}^{2}+\sigma_{\mathrm{W}}^{2}}$, with $\sigma_{\mathrm{B}}^{2}$ and $\sigma_{\mathrm{W}}^{2}$ the between-group and within-group components of variance analysis.

The numerator contains an estimate of $2 / 3$ of the dominance variance and is thus an overestimation of $h^{2}$ in the narrow sense, to a larger extent than in half-sib or even full-sib designs.

The computations of standard errors of $h^{2}$ were adapted from those given in Becker (1985) for unequal number of progenies per group.

\section{LITERATURE CITED}

Amend DF, Nelson JR (1977) Variation in the susceptibility of sockeye salmon to infectious hematopoietic necrosis. J Fish Biol 11:567-573

Béarzotti M, Delmas B, Lamoureux A, Loustau AM, Chilmonczyk S, Brémont M (1999) Fish rhabdovirus cell entry is mediated by fibronectin. J Virol 73(9):7703-7709

Becker WA (1985) Manual of quantitative genetics, 4th edn, 2nd printing. Academic Enterprises, Pullman, WA

Billard R (1977) Utilisation d'un système tris-glycocolle pour tamponner le dilueur d'insémination pour truite. Bull Fr Piscic 264:102-112

Boudinot P, Blanco M, De Kinkelin P, Benmansour A (1998) Combined DNA immunization with the glycoprotein gene of viral hemorrhagic septicemia virus and infectious hematopoietic necrosis virus induces double-specific protective immunity and non specific response in rainbow trout. Virology 249:297-306
Chen MF, Aikens CM, Fryer JL, Rohovec JS (1990) Virulence of four isolates of infectious hematopoietic necrosis virus in salmonid fishes and comparative replication in salmonid cell lines. Calif Fish Game 76:137-145

Chevassus B, Dorson M (1990) Genetics of resistance to disease in fishes. Aquaculture 85:83-107

Chilmonczyk S (1980) Some aspects of trout gill structure in relation to Egtved virus infection and defence mechanisms. In: Ahne W (ed) Fish diseases. Springer-Verlag, Berlin, p 18-22

Chourrout D (1982) Gynogenesis caused by ultraviolet irradiation of salmonid sperm. J Exp Zool 223:175-181

Chourrout D, Quillet E (1982) Induced gynogenesis in the rainbow trout: sex and survival of progenies. Production of all-triploid populations. Theor Appl Genet 63:201-205

Cousin-Gerber M, Burger G, Boisseau C, Chevassus B (1989) Effect of methyltestosterone on sex differentiation and gonad morphogenesis in rainbow trout Oncorhynchus mykiss. Aquat Liv Resour 2:225-230 
De Kinkelin P (1988) Vaccination against haemorrhagic septicaemia. In: Ellis AE (ed) Fish vaccination. Academic Press, London, p 172-192

De Kinkelin P, Leberre M (1977) Isolement d'un rhabdovirus pathogène de la truite fario (Salmo trutta L.). C R Hebd Séances Acad Sci 284:101-104

De Kinkelin P, Chilmonczyk S, Dorson M, Leberre M, Baudouy AM (1979) Some pathogenic facets of rhabdoviral infection of salmonid fish. In: Bachmann PA (ed) Proceedings of the 4th Munich Symposium on Microbiology on Mechanisms of Viral Pathogenesis and Virulence. WHO, Munich, p 357-375

Diter A, Quillet E, Chourrout D (1993) Suppression of first egg mitosis induced by heat shocks in the rainbow trout. J Fish Biol 42:777-786

Dorson M, Chevassus B (1985) Etude de la réceptivité d'hybrides triploïdes truite arc-en-ciel $\times$ saumon coho à la nécrose pancréatique infectieuse et à la septicémie hémorragique virale. Bull Fr Pêche Pisc 296:29-34

Dorson M, Torhy C (1993a) Viral haemorrhagic septicaemia virus replication in external tissue excised from rainbow trout, Oncorhynchus mykiss (Walbaum), and hybrids of different susceptibilities. J Fish Dis 16:403-408

Dorson M, Torhy C (1993b) Viral haemorrhagic septicaemia virus replication in organs from rainbow trout and hybrids of different susceptibilities. Book of abstracts of the EAFP 6th conference, 3 (poster), Brest, 5-10 Sept

Dorson M, Torhy C (1994) Viral haemorrhagic septicaemia virus replication and interferon production in organs excised from resistant and susceptible trout. Abstracts of the International Symposium on Aquatic Animal Health, Seattle, Washington, 4-8 Sept

Dorson M, Chevassus B, Torhy C (1991) Comparative susceptibility of three species of char and of rainbow trout $\times$ char triploid hybrids to several pathogenic salmonid viruses. Dis Aquat Org 11:217-224

Dorson M, Quillet E, Hollebecq MG, Torhy C, Chevassus B (1995) Selection of rainbow trout resistant to viral haemorrhagic septicaemia virus and transmission of resistance by gynogenesis. Vet Res 26:361-368

Estepa A, Frias D, Coll JM (1993) In vitro susceptibility of rainbow trout fin cells to viral haemorrhagic septicaemia virus. Dis Aquat Org 15:35-39

Estoup A, Presa P, Krieg F, Vaiman D, Guyomard R (1993) $(\mathrm{CT})_{\mathrm{n}}$ and $(\mathrm{GT})_{\mathrm{n}}$ microsatellites: a new class of genetic markers for Salmo trutta L. (brown trout). Heredity 71: 488-496

Estoup A, Gharbi K, SanCristobal M, Chevalet C, Haffray P, Guyomard R (1998) Parentage assignment using microsatellites in turbot (Scophtalmus maximus) and rainbow trout (Oncorhynchus mykiss) hatchery populations. Can J Fish Aquat Sci 55:715-725

Falconer DS (1989) Introduction to quantitative genetics, 3rd edn. Longman Scientific \& Technical, Co. published with Wiley \& Sons, Inc., New York

Fijan N, Sulimanovic D, Béarzotti M, Muzinic D, Zwillenberg LO, Chilmonczyk SC, Vautherot JF, De Kinkelin P (1983) Some properties of the epithelioma papulosum cyprini (EPC) cell line from Carp, Cyprinus carpio. Ann Virol (Institut Pasteur) 134E:207-220

Fjalestad KT, Gjedrem T, Gjerde B (1993) Genetic improvement of disease resistance in fish: an overview. Aquaculture 111:65-74

Henryon M, Jokunsen A, Berg P, Lund I, Pedersen PB, Olesen NJ, Slierendrecht WJ (2001) Genetic variation for growth rate, feed conversion efficiency and disease resistance exists within a farmed population of rainbow trout. Aqua- culture (in press)

Jensen MH (1965) Research on the virus of Egtved disease. Ann NY Acad Sci 126:422-426

Kaastrup P, Horlyck V, Olesen NJ, Lorenzen N, Vestergaard Jorgensen PE (1991) Paternal association of increased susceptibility to viral haemorrhagic septicaemia (VHS) in rainbow trout (Oncorhynchus mykiss). Can J Fish Aquat Sci 48:1188-1192

Kocan R, Bradley M, Elder N, Meyers T, Batts W, Winton J (1997) North American strain of viral hemorrhagic septicemia virus is highly pathogenic for laboratory-reared Pacific herring. J Aquat Anim Health 9:279-290

Konrad M, Weiland F, Enzmann PJ (1989) Immunohistological studies on the pathogenesis of viral haemorrhagic septicaemia (VHS) in rainbow trout. In: Lillehund K, Rosenthal $\mathrm{H}$ (eds) Fish health protection strategies. Federal Ministry for Research and Technology, Hamburg, p 121-134

Lapatra SE, Rohovec JS, Fryer JL (1989) Detection of infectious hematopoietic necrosis virus in fish mucus. Fish Pathol 24:197-202

Lorenzen N, Olesen NJ, Koch C (1999) Immunity to VHS virus in rainbow trout. Aquaculture 172:41-61

McIntyre JD, Amend DF (1978) Heritability of tolerance for infectious hematopoietic necrosis in Sockeye salmon (Oncorhynchus nerka). Trans Am Fish Soc 107:305-308

Neukirch M (1984) An experimental study of the entry and multiplication of viral haemorrhagic septicaemia virus in rainbow trout, Salmo gairdneri Richardson, after waterborne infection. J Fish Dis 7:231-234

Neukirch M (1985) Uptake, multiplication and excretion of viral haemorrhagic septicaemia virus in rainbow trout (Salmo gairdneri). In: Ellis AE (ed) Fish and shellfish pathology. Academic Press, London, p 295-300

Okamoto N, Tayama T, Kawanobe M, Fujiki N, Yasuda Y, Sano T (1993) Resistance of a rainbow trout strain to infectious pancreatic necrosis. Aquaculture 117:71-76

Palti Y, Parsons JE, Thorgaard G (1999) Identification of candidate DNA markers associated with IHN virus resistance in backcrosses of rainbow (Oncorhynchus mykiss) and cutthroat trout (O. clarki). Aquaculture 173:81-94

Price DJ (1985) Genetics of susceptibility and resistance to disease in fishes. J Fish Biol 26:509-519

Ristow S, Grabowski LD, Ostberg C, Robison B, Thorgaard GH (1998) Development of long-term cell lines from homozygous clones of rainbow trout. J Aquat Anim Health 10:75-82

Rodriguez F, Lapatra SE, Williams SR, May B (1999) Identification of molecular genetic markers for infectious hematopoietic necrosis resistance in rainbow trout. VIIth International Plant and Animal Genome Conference, January 17-21, 1999, San Diego, CA. Final program and abstracts guide, poster abstract no. P125, p 109

Sakamoto T, Okamoto N, Ikeda Y (1994) Dinucleotide repeat polymorphism of rainbow trout, FGT2. J Anim Sci 72:2765

Slierendrecht WJ, Jensen LB, Horlyck V, Koch C (1993) Genetic polymorphism of complement component $\mathrm{C} 3$ in rainbow trout (Oncorhynchus mykiss) and resistance to viral haemorrhagic septicaemia. Fish Shellfish Immunol 3:199-206

Slierendrecht WJ, Olesen NJ, Lorenzen N, Jorgensen PEV, Gottschau A (1994) The production of two gynogenetic strains of rainbow trout (Oncorhynchus mykiss) with different resistance to viral haemorrhagic septicaemia. Aquaculture 137:278 (abstract)

Slierendrecht WJ, Olesen NJ, Lorenzen N, Jorgensen PEV, Gottschau A, Koch C (1996) Genetics alloforms of rainbow trout (Oncorhynchus mykiss) complement component C3 
and resistance to viral haemorrhagic septicaemia virus under experimental conditions. Fish Shellfish Immunol 6: 235-237

Stoker M, MacPherson I (1961) Studies on transformation of hamster cells by polyoma virus in vitro. Virology 14 : 359-370

Trobridge GD, Lapatra SE, Kim CH, Leong JC (2000) Mx mRNA expression and RFLP analysis of rainbow trout Oncorhynchus mykiss genetic crosses selected for susceptibility or resistance to IHNV. Dis Aquat Org 40:1-7

Van Muiswinkel WB, Wiegertjes GF, Stet RJM (1999) The influence of environmental and genetic factors on the disease resistance of fish. Aquaculture 172:103-110

Winton JR, Batts WN, Nishizawa T, Stehr CM (1989) Characterization of the first North American isolates of viral hemorrhagic septicaemia virus. Am Fish Soc, Fish Health Sect Newsl 17:2

Yamamoto T, Clermont TJ (1990) Multiplication of infectious hematopoietic necrosis virus in rainbow trout following immersion infection: organ assay and electron microscopy. J Aquat Anim Health 2:261-270

Yamamoto T, Hu K (1991) Infectious pancreatic necrosis virus

Editorial responsibility: Jo-Ann Leong,

Corvallis, Oregon, USA infection of trout epidermis. In: Fryer JL (eds) Proceedings of 2nd International Symposium on Viruses of Lower Vertebrates. Oregon State University, Corvallis, p 235 (abstract)

Yamamoto T, Batts WN, Arakawa CK, Winton JR (1990a) Multiplication of infectious hematopoietic necrosis virus in rainbow trout following immersion infection: whole body assay and immunochemistry. J Aquat Anim Health 2: $271-280$

Yamamoto T, Hu K, Batts WN, Winton JR (1990b) Infection of fish skin and the transmission of salmonid virus diseases. In: Habermehl KO, Zeichhardt $\mathrm{H}$ (eds) VIIIth Congress of Virology. Institute for Clinical and Experimental Virology, Berlin, p 488 (abstract)

Yamamoto S, Sanjyo I, Sato R, Kohara M, Thara H (1991) Estimation of the heritability for resistance to infectious hematopoietic necrosis in rainbow trout. Bull Jpn Soc Sci 57:1519-1522

Yamamoto T, Batts WN, Winton JR (1992) In vitro infection of salmonid epidermal tissues by infectious hematopoietic necrosis virus and viral haemorrhagic septicaemia virus J Aquat Anim Health 4:231-239

Submitted: June 29, 2000; Accepted: March 12, 2001 Proofs received from author(s): June 18, 2001 